\title{
Human Dignity in the Netherlands
}

\author{
Jan-Peter Loof
}

\section{Abstract}

This contribution contains an overview of the role of the concept of human dignity in the Dutch constitutional system. The role is a very limited one, mainly due to the rather sober constitutional culture and tradition in the Netherlands. The Constitution does not contain any reference to human dignity, nor do the Netherlands have a system of constitutional review of Acts of Parliament by the judiciary. Sometimes, the idea of human dignity does play a role in legal debates in Parliament or in court decisions. In most cases, this is the result of the application of international and European human rights standards and the taking into consideration of interpretations given by bodies like the European Court of Human Rights. However, there are some eye-catching judgements in which Dutch courts have taken some extra steps in considering human dignity.

\section{Keywords}

Constitutional law $\bullet$ Constitutional tradition • Human dignity • Human rights • Soberness • The Netherlands

\section{Contents}

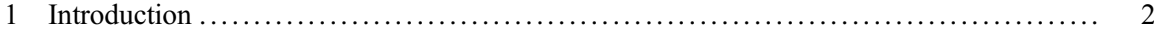

2 Human Dignity in the Constitution of the Netherlands $\ldots \ldots \ldots \ldots \ldots \ldots \ldots \ldots \ldots \ldots \ldots \ldots 2$

2.1 No Constitutional Provisions Referring to Human Dignity .................... 2

2.2 A "Sober" Constitutional Tradition $\ldots \ldots \ldots \ldots \ldots \ldots \ldots \ldots \ldots \ldots \ldots \ldots \ldots \ldots \ldots \ldots \ldots \ldots$

2.3 No Constitutional Review of Acts of Parliament $\ldots \ldots \ldots \ldots \ldots \ldots \ldots \ldots \ldots \ldots \ldots \ldots \ldots 6$

2.4 Direct Applicability of International Law Standards in the Dutch Legal System . . . 6

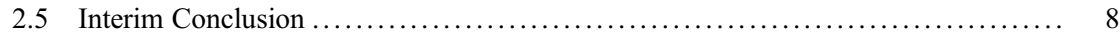

3 Recent Proposals to Incorporate Human Dignity in the Netherlands' Constitution ....... 8

3.1 Proposal by the Royal Commission for the Constitution in $2010 \ldots \ldots \ldots \ldots \ldots \ldots$. 8

\footnotetext{
J.-P. Loof $(\square)$

Faculty of Law, Leiden University, Leiden, The Netherlands

e-mail: j.p.loof@law.leidenuniv.nl
} 
3.2 Government Reaction to the Proposal by the Royal Commission ............... 11

4 References to Human Dignity in Legislation ................................... 12

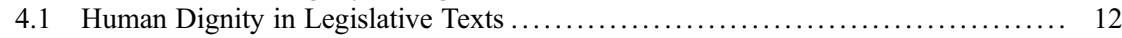

4.2 Human Dignity as an Argument for Legislative Proposals .................... 13

5 Application of the Idea of Human Dignity in Dutch Case Law ..................... 15

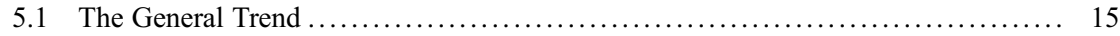

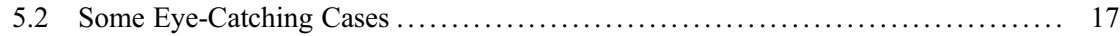

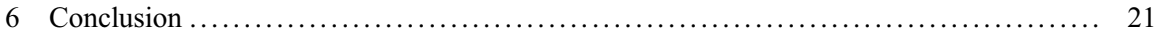

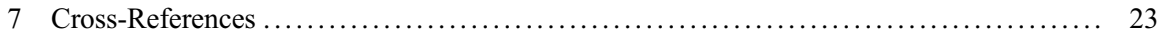

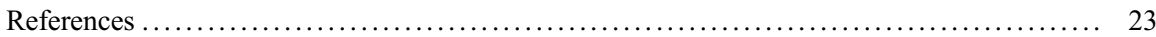

\section{Introduction}

This contribution explores the role of human dignity in the constitutional system of the Netherlands. In what way are human dignity-related norms part of the constitutional framework? Is there a role for human dignity besides the human rights standards that are enshrined in the Dutch constitution? And if so, what is its legal status? Can human dignity norms be invoked before Dutch courts?

In order to shed some light on these questions, the author first investigates the text of the Dutch Constitution as well as Dutch constitutional history and tradition $(\S 1)$. In the second phase of the investigation, he discusses some recent proposals for constitutional amendments in which human dignity was a key factor $(\S 2)$. After that, he inquires whether human dignity is referred to in ordinary legislation $(\S 3)$ and in case law of the Dutch courts $(\S 4)$. In $\S 5$, the author summarises his findings.

\section{Human Dignity in the Constitution of the Netherlands}

\subsection{No Constitutional Provisions Referring to Human Dignity}

The current Constitution of the Netherlands does not contain any provision that refers to the inviolability of human dignity. Although there is a strong tradition in Dutch constitutional law to codify concepts like equality before the law, individual freedom and protection of fundamental rights, specific references to human dignity are lacking. References to equality of individuals, individual freedom and protection of fundamental rights can already be found in the very first constitutional document for the Low Countries of the modern era: the Staatsregeling voor het Bataafse Volk (State Regulation of the Batavian People) from 1798, a document inspired and influenced by the French Revolution. In fact, a constitutional provision that comes closest to the idea of human dignity, in the sense that it indirectly refers to respect for all individuals in society, might even be found in that very first constitutional document also. Article 6 of the 1798 Staatsregeling stated: "Alle de pligten van den Mensch in Maatschappij hebben hunnen grondslag in deze heilige wet: Doe eenen ander niet, hetgeen gij niet wenscht dat aan u geschiede" (All duties of the 
individual in society spring from this holy law: do not do unto others what you would not want done to yourself).

Besides this, Article 6 of the 1798 Staatsregeling - which preceded the first Constitution (Grondwet) enacted in 1815, after the Netherlands had regained its independence the from the French empire and the Kingdom was established under the house of Oranje-Nassau - there is no single reference to human dignity in any of the provisions of the Dutch Constitution. Nor has there ever been one. One of the reasons for this might be the fact that the Dutch Constitution does not contain a preamble. A preamble might be a "logical" place for references to concepts that underlie the basic assumptions or the systemic features of the Constitution. Although there have been discussions on the incorporation of a preamble in the Constitution, in the early 1970s and also in more recent years (2006-2010), an actual draft for a preamble was never presented to parliament. In 1971, the Royal Advisory Commission that played an important role in preparing the general revision of the Constitution which would enter into force in 1983 (see below in Sect. 2.2) shortly played with the idea of adding a preamble to the Constitution. However, the commission considered that a preamble, either containing an attachment to certain values and principles or a declaration of national unity, would run the risk of becoming a criterion against which all government policies would be judged in the public debate. And in the eyes of the commission, this was undesirable (Final report of the Royal Advisory Commission on the Constitution and the Electoral Law 1971).

Certainly the most important instruments for identifying a general concept of human dignity are the founding documents of the modern international system, the UN Charter and the Universal Declaration of Human Rights (UDHR). The UN Charter was the first international legal document mentioning dignity in its preamble, and the UDHR was the first human rights document mentioning dignity. Many subsequent human rights instruments refer to the UDHR's allusion to human dignity in their preambles. Actually, these developments in international law and the establishment of legal mechanisms and institutions of European cooperation were driving forces behind some constitutional amendments that took place in the Netherlands in 1953 and 1956. These amendments resulted in the introduction of several provisions concerning the relation between the national legal system and international (treaty) law (which will be discussed in Sect. 2.4). However, the adding to the Constitution of any provisions containing references to the idea of human dignity were not considered at that time. In order to understand the Dutch constitutional unawareness of the idea of human dignity, one needs to understand the constitutional culture in the Netherlands. I will elaborate on some further reasons for the lack of a provision concerning human dignity in the next sections.

\subsection{A "Sober" Constitutional Tradition}

The lack of a provision referring to the idea of human dignity can be seen as a result of the general legislative approach towards the Constitution in the past decades. The 
last integral revision of the Dutch Constitution took place during a period of almost two decades in the 1960s, 1970s and early 1980s and resulted in a "new" Constitution that entered into force in 1983. The first Chapter of this new Constitution (Articles 1-23) brought together all provisions concerning the protection of fundamental rights, civil and political rights as well as social and economic rights. Fundamental rights that are often considered to be closely linked to human dignity, such as the right to protection of private life (Art. 10) and the right to physical integrity (Art. 11), were newly introduced in the first Chapter of the Dutch Constitution as a result of the 1983 revision. After 1983, no structural changes in the Constitution took place (an English translation of the current Dutch Constitution can be found at http://legislationline.org, a website maintained by the OSCE Office for Democratic Institutions and Human Rights).

In addition to updating the constitutional provisions on fundamental rights, one of the main reasons for the integral revision of the Constitution in that period was the general political wish for constitutional deregulation or "deconstitutionalisation" (Kroes and Gerbranda 1993; Barkhuysen et al. 2009). The Constitution should be modernised and simplified in a systematic fashion in order to confine it to its essentials, to make it more concise and more comprehensible for people without legal training. The Constitution in its form before the 1983 revision was a lengthy document that consisted of 13 chapters, some of which were subdivided into different sections. This form basically reflected nineteenth century views on the structure of the state. For instance, it contained a large chapter on the position of the King, with provisions regulating all kinds of details on the investiture and the powers of the King. These provisions in particular gave the impression that an important part of the power of the state lay in the hands of the King, which was no longer the case since the introduction of the parliamentary rule of ministerial responsibility in 1848: "The Ministers, and not the King, shall be responsible for acts of government" (Article $42 \S 2$ of the current Dutch Constitution).

Also, constitutional deregulation was preferred for practical reasons. The Dutch Constitution is a relatively rigid one, in the sense that adaptions to the Constitution require a longer and more complicated legislative process in parliament than ordinary laws. The procedure for the revision of the Constitution prescribes a double discussion in parliament: discussion by the two parliamentary chambers in sessions, followed by a second discussion in both chambers subsequently, after general elections for the Second Chamber of parliament have been held. And in that second discussion, acceptance of the Bill to adapt the Constitution requires a two-thirds majority in both chambers (see Articles 137-139 of the current Dutch Constitution). The idea behind this entrenchment is that it warrants a large support for constitutional amendments. The downside is that it puts the parliamentary minority in a position to block proposed adaptions of the Constitution, which in practice might and indeed does - cause a considerable preserving and conservative effect. Out of anxiety for this latter effect, in the decades leading up to the 1983 revision, it was considered that a Constitution with a very detailed regulation of the parliamentary system and of decision-making processes would run the risk of acting as an obstacle in finding pragmatic solutions for immanent problems and new developments in 
society. Therefore, the 1983 revision resulted in a "thinning out" of the excessive detail in many areas of the Constitution. The broadly supported view was that, in general, the Constitution should only contain the main lines of the political system and the further elaboration should be left to ordinary legislation. There was at the time certainly no intention of introducing fundamental or politically disputed alterations in the existing constitutional law, even though lengthy discussions were held with regard to the electoral system. The basic structure of the Dutch constitutional system was not disputed to any great degree: a parliamentary democracy under a constitutional monarch; a parliamentary system of government, in which the King has no political power (he fulfills a largely ceremonial role, although he does have a certain influence in advising) and the political power of the ministers depends on the confidence of a majority in parliament, its Second Chamber in particular.

With this pragmatic attitude towards the Constitution came a sense of soberness regarding its content: no excessively detailed provisions and, consequently, no sweeping statements or considerations on the sources of the pouvoir constituante or other principles underlying the constitutional system. That the function of the Constitution within the Dutch constitutional system had been altered was clear before the general revision entered into force in 1983. Whereas during the nineteenth century the Constitution was considered to be the legal basis of the political system and major political questions were expressed in terms of constitutional considerations, during the twentieth century this intention was absent. The nineteenth century twofold approach of (1) amending the Constitution in an integral manner as far as possible to altered circumstances and opinions and (2) using the Constitution as an instrument to influence societal changes, faded away. In the early twentieth century, a number of important political conflicts were still solved by means of constitutional alterations. The constitutional revision of 1917 resolved two huge political conflicts by, on the one hand, introducing the general right to vote and changing the voting system and, on the other hand, guaranteeing full financing of private schools by public funding. In later decades, the tendency to leave the Constitution intact and only adopt incidental amendments when the circumstances required became leading. Political conflicts were dealt with outside the context of constitutional adaptions. In the past 50 years, Parliament never was dissolved in order to organise elections for the mere reason that these elections were a necessary part of the procedure for constitutional amendments. Whenever a bill to adapt the Constitution was accepted by both chambers of Parliament in first discussion, the second discussion of this bill was simply delayed until after the next regularly planned general elections. As a result of this practice, the constitutional amendments did not receive much attention during the election campaigns. These campaigns were most of the time dominated by debates on socio-economic instead of constitutional issues. As one commentator reflected: "[P]olitical parties are not inclined to treat constitutional amendments as important planks in their political platforms" (Alkema 1984). The fact that after 1983 we have seen only marginal and technical adaptions of the Constitution has added to this political attitude. Actually, in recent decades, the government indicated several times that a certain issue needed to reach a certain level of "constitutional ripeness", i.e., a sufficient amount of fine tuning in jurisprudence 
and case law, before incorporation in the Constitution would even be considered (Kamerstukken I (Parliamentary Papers of the First Chamber) 2012/13, 31570, G). Thus, the Dutch Constitution is not viewed as a way to modify changes in society, but rather as a way to codify changes that have become evident in constitutional practice or in the case law of the highest courts.

\subsection{No Constitutional Review of Acts of Parliament}

Another factor influencing the constitutional unawareness with regard to human dignity is the fact that, in general, the Dutch Constitution does not play a leading role in the debate on human rights and fundamental freedoms in the Netherlands. There are two important reasons for this.

Firstly, Article 120 of the Constitution prohibits constitutional review of Acts of Parliament by the judiciary: "The constitutionality of Acts of Parliament and treaties shall not be reviewed by the courts." Thus, Article 120 stands in the way of developing a constitutional debate in the courts on issues like the scope of fundamental rights and justified limitations to fundamental rights. Secondly, the restriction clauses of most of the fundamental rights provisions in the first Chapter of the Dutch Constitution merely indicate that it is up to the legislature to decide which restrictions on the enjoyment of the right are allowed. For instance, in the Articles 10 and 11 (already mentioned in Sect. 2.1), the right to privacy and the right to physical integrity are guaranteed "without prejudice to restrictions laid down by or pursuant to Act of Parliament". At the time of the 1983 revision the legislature, in particular parliament, was seen as the chief protector of fundamental rights. The leading line of thinking was that the exchange of arguments and views in parliamentary debate would lead to well-balanced restrictions of rights. The constitutional restriction clauses do not contain any requirements concerning the necessity or proportionality of interferences with fundamental rights. Thus, they do not provide much of a guiding framework for the legislative process with regard to rights restrictions. In the Dutch legal system, this guiding role is mainly played by the provisions of human rights treaties, in court proceedings as well as in the legislative process.

\subsection{Direct Applicability of International Law Standards in the Dutch Legal System}

The important role of ECHR provisions in the legal debate on human rights in the Netherlands also is a result of the openness of Dutch constitutional law vis-à-vis international law. The Netherlands' system concerning the interaction between international law and the domestic legal order can be qualified as moderately monistic. The Constitution sets only a limited number of conditions for the internal effect of international law, such as parliamentary approval and official publication. This can be seen in Articles 91 and 93. Article $91 \S 1$ reads: 
The Kingdom shall not be bound by treaties, nor shall such treaties be denounced without the prior approval of the States General. The cases in which approval is not required shall be specified by Act of Parliament.

Article 93 reads:

Provisions of treaties and of resolutions by international institutions which may be binding on all persons by virtue of their contents shall become binding after they have been published.

Article 94 adds to this the following:

Statutory regulations in force within the Kingdom shall not be applicable if such application is in conflict with provisions of treaties or of resolutions by international institutions that are binding on all persons.

These Articles of the Constitution lend direct effect to provisions of international law, at least provisions of treaties and of decisions of international organisations, on the condition that they are "binding on all persons", i.e., that they are self-executing. Individuals can invoke self-executing treaty provisions in procedures before the Dutch courts and these treaty provisions even enjoy priority over Acts of Parliament as well as over the Constitution itself. The courts will apply the treaty standards and may even quash Acts of Parliament and other domestic statutory regulations for non-conformity with self-executing treaty provisions - although in practice the courts also seek room to, often implicitly, interpret national law provisions in a treaty-conform way. Occasionally, the courts have preferred to "abstain" by ruling that even if the treaty provision is to be considered self-executing, it would, in the circumstances of the case at hand, lie outside their competence to apply the treaty provision and let it prevail over domestic statutory provisions. This is particularly so when those circumstances call for a weighing of different alternatives that the courts deem is beyond their judicial task and rather a matter for the political branch to decide (Alkema 2012; Uzman et al. 2010).

As a result of this, the legal debate on fundamental rights in the Netherlands is centred on the relevant provisions of human rights treaties instead of the comparable constitutional provisions. In particular, the civil and political rights laid down in the European Convention on Human Rights (ECHR) and the International Covenant on Civil and Political Rights (ICCPR) dominate the legal debate. Most of these rights are considered to be self-executing and the restriction clauses in both treaties do contain more material limits - requirements of necessity and proportionality regarding interferences with the protected rights. In applying treaty standards, the courts incorporate the interpretation by the European Court of Human Rights (ECtHR) and the UN Human Rights Committee of those standards. Thus, both the courts and the administration when applying these norms strongly subscribe and defer to case law of the international supervising bodies.

In contrast, the UDHR and its strong preambular references to "the inherent dignity and of the equal and inalienable rights of all members of the human family", 
is not a huge factor in the legal human rights debate or in court procedures in the Netherlands. In 1984, the Supreme Court characterised the UDHR as a non-binding declarative text that does not lend itself for direct internal application like binding treaty standards (Hoge Raad (Supreme Court) 7 November 1984, Nederlandse Jurisprudentie (Dutch Case Law) 1985, 247). Although it would have been conceivable that it had examined whether the UDHR had acquired binding force as customary international law, the Supreme Court chose not to do so. This Supreme Court decision had a chilling effect on later attempts to inject the aspiring UDHR language in the legal human rights debate.

\subsection{Interim Conclusion}

The Constitution of the Netherlands does not contain any reference to the inviolability of human dignity, although it does contain a fairly elaborated human rights catalogue of civil and political rights as well as economic and social rights. However, the constitutional human rights provisions only play a marginal and subordinate role in the legal debate. In the Netherlands, there is hardly any legal debate on human rights issues outside of or in addition to the international framework of human - in particular civil and political - rights treaties. This is influenced by the double (and seemingly contradictory) fact that on the one hand self-executing human rights treaty provisions can be directly applied by the courts whereas, on the other hand, constitutional review of Acts of Parliament by the judiciary is prohibited. Therefore, references to the concept of human dignity in the Dutch legal order can only be found in as far as they give guidance to the interpretation of human rights treaty provisions and in as far as they are used by the international supervising bodies.

\section{Recent Proposals to Incorporate Human Dignity in the Netherlands' Constitution}

\subsection{Proposal by the Royal Commission for the Constitution in 2010}

After all that has been described in Sect. 1, it may come as a surprise that, quite recently, there has been a proposal to incorporate a provision on human dignity in the Constitution of the Netherlands. The background of this proposal was the political wish of the Minister of the Interior and the Minister of Justice to increase the public awareness of the Constitution as a document containing the "fundamental values and principles" underlying Dutch society.

Around 2005, the political sentiment was that the Constitution needed to be revitalised. The Constitution should become more of a "living document", an inspiring source of common fundamental values and principles that might create a sense of shared identity for the citizens. A number of initiatives were taken to consult "ordinary" citizens on their thoughts and wishes regarding the content of the 
Constitution. One of these initiatives was the Nationale Conventie (National Convention), an advisory body created by ministerial decree, consisting of a mix of members of political parties, scholars, representatives of civil society, journalists, opinion leaders and young individuals that was asked to present "a coherent set of proposals that could form the basis for the Dutch Constitution of the 21th century". In November 2006, this Nationale Conventie presented its views on the Constitution. Inter alia, the Convention recommended that (1) a broad societal debate should be organised on the need for and possible contents of a preamble to the Constitution and (2) a chapter with general provisions should be added to the Constitution. These general provisions should indicate the fundamental principles of the constitutional system.

Due to political turmoil in the given period, the views of the National Convention did not receive any follow-up. However, in 2009, the Cabinet decided to install a Royal Commission to prepare proposals for possible amendments to the Constitution. The amendments should in particular be focused on increasing the accessibility of the Constitution for the general public, on strengthening the normative power of the Constitution and on streamlining the constitutional fundamental rights provisions with the provisions of human rights treaties (Kamerstukken II (Parliamentary Papers of the Second Chamber) 2008/09, 31570 and Kamerstukken I (Parliamentary Papers of the First Chamber) 2008/09, 31700 VII, F).

Part of the work of the Royal Commission was further studies on the pros and cons of a preamble (Cliteur and Voermans 2009) and of a constitutional reference to the concept of human dignity. This second study was prepared by two Flemish scholars: Eva Brems and Jogchum Vrielink. On the basis of an international comparison of relevant constitutional and treaty provisions Brems and Vrielink identified a number of different roles that the concept of human dignity can play in a constitutional order: from (1) being a foundation for the protection of human rights, to (2) functioning as a guiding principle for the interpretation of several specific human rights, (3) acting in itself as an autonomous human right and (4) setting limits to human rights restrictions (Brems and Vrielink 2010). Their study also included an inventory of the arguments in favour and against the different constitutional roles of human dignity. Both scholars left the evaluation of those arguments to the Royal Commission itself.

In its final report, published in November 2010, the Royal Commission turned out to be in favour of the inclusion of a general provision in the Constitution. This was preferred over the introduction of a preamble. In the eyes of the Royal Commission, this general provision should include a reference to democracy, rule of law and several aspects thereof as an expression of not only the fact that the Netherlands is a democratic state under the rule of law, but also of the continuing aspiration to be such a state. The Royal Commission considered that several provisions in the Dutch Constitution already implicitly express some fundamental principles for the organisation of government, the exercise of public authority and the relation between the state and the citizens: democracy, separation of powers, the principle of legality, respect for fundamental rights and liberties, access to an independent judiciary etc. Making those fundamental principles more explicit by referencing them in a general 
provision would have the advantage of a higher level of recognisability of these principles for the general public. It would also have the advantage of improving the framework for the interpretation of constitutional human rights provisions, thus strengthening the normative power of the Constitution. According to the Royal Commission, explicit reference to those fundamental principles and values in a general provision to the Constitution would stress the requirement for all state powers - legislature, executive and judiciary - to act in accordance with them (Rapport Staatscommissie Grondwet (Report of the Royal Commission on the Constitution) 2010).

The Royal Commission proposed the following draft for a general provision, which was supposed to be included in the Constitution before the first Article. The text for this draft provision read as follows (Eng. translation by author):

1. The Netherlands is a democratic state under the rule of law.

2. The government shall respect and secure human dignity, human rights and fundamental legal principles.

3. The exercise of public authority shall be based exclusively on the Constitution or an Act of Parliament.

The Royal Commission explained the incorporation of human dignity in the second paragraph inter alia by referring to the case law of the ECtHR, in which "respect for human dignity and human freedom" is seen as "the very essence" of the ECHR (I. v. The United Kingdom 2002; Goodwin v. The United Kingdom 2002; Jehovah's witnesses of Moscow v. Russia 2010) and the Court of Justice of the European Union (CJEU), which has made clear that "the Community legal order undeniably strives to ensure respect for human dignity as a general principle of law" (Omega Spielhallen 2004). The Royal Commission considered that the incorporation of the concept of human dignity in the Constitution could serve as a framework for the interpretation of several other rights in the Constitution, such as the right to physical integrity and the prohibition of degrading treatment, and as a point of orientation for making choices in cases of conflicting rights and for demarcating the very essence (hard core) of certain rights. This last role for the concept of human dignity related to another proposal by the Royal Commission: the introduction of a clause in the fundamental rights chapter of the Constitution that a restriction to one of the rights should never interfere with the very essence of that right.

The Royal Commission pointed to the fact that human dignity included the aspect of individual self-determination and personal autonomy: within certain limits, every individual should have the right to act on the basis of his or her own ideas concerning the arrangement of one's life, instead of on the basis of the ideas of the government. It also pointed to the fact that within the concept of human dignity, several aspects might clash in certain situations and that a general rule of priority would be impossible to establish since it would be highly dependent on the specific circumstances of a case. Notwithstanding these uncertainties, the commission concluded that incorporating human dignity in this general provision in the Constitution would have added value. 


\subsection{Government Reaction to the Proposal by the Royal Commission}

In October 2011, the government published its reaction to the proposals by the Royal Commission. By that time, the government coalition had changed as a result of the general elections of 2010. The new government was far less enthusiastic towards ideas of increasing the accessibility and understanding of the Constitution for the general public by way of textual amendments. In just a few paragraphs, the government expressed that it would not follow the commission's proposal for the inclusion of a general provision in the Constitution. The government explained that the introduction of a general provision could be considered as part of a strategy to strengthen the "societal and educational function" of the Constitution and to transform the Constitution into "a more evocative, inspiring and declaratory document". However, after careful consideration, the government saw no good reasons for such a strategy. Adapting the function of the Constitution was considered in breach of the sober constitutional tradition in the Netherlands. Furthermore, the government argued that adapting the function of the Constitution would require a larger operation than the mere introduction of a general provision at the beginning of Chapter 1 of the Constitution. And the government simply saw no sufficient reason to start such a larger operation. Finally, the government showed itself weary of a larger role for the judiciary in the interpretation of constitutional rights as a result of the inclusion of a general provision referring to human dignity, given the lack of precision of the concept as such (Kamerstukken II (Parliamentary Papers of the Second Chamber) 2011/12, 31570, 20).

In particular, in the First Chamber of Parliament (the Senate), the reluctance of the government to introduce a general provision in the Constitution referring to the fundamental values and principles underlying the Constitution met substantial resistance. In February 2012, a majority of the First Chamber agreed on a motion demanding the government to bring a bill to parliament in order to add a general provision to the Constitution. According to the First Chamber, at the very least, this general provision needed to express the fact that the Netherlands is a democratic state under the rule of law (Kamerstukken I (Parliamentary Papers of the First Chamber) 2011/12, 31570, B). Although at first the government again showed its great reluctance concerning a general provision (Kamerstukken I (Parliamentary Papers of the First Chamber) 2012/13, 31570, G), after a second debate in the First Chamber, it accepted the majority's wish and promised to develop a draft for a general provision in the course of 2014. Indeed in 2014, a draft general provision was published. It turned out to be a very brief text: "The Constitution secures democracy, rule of law and human rights" (Eng. translation by author). The idea of a reference to human dignity was left aside by the government. Many scholars criticised this draft for its lack of ambition and guidance. The Dutch National Human Rights Institute (College voor de Rechten van de Mens) published an advisory opinion stating that the draft provision did not add anything to the Constitution and again called for inclusion in a general provision of the idea of human dignity, which would at least give the general provision some kind of steering character 
with regard to other provisions of the Constitution (College voor de Rechten van de Mens 2014).

After the publication of the draft for a general provision in the autumn of 2014, the government remained silent on the issue. The Council of State was asked to give advice on the draft general provision, which is the common procedure in the Netherlands before a bill is presented to Parliament. The Council showed very little enthusiasm for the draft text. However, rather recently, in July 2016, a bill containing a general provision was sent to Parliament, with basically the same text as the draft from 2014. In the explanatory memorandum, the government refers to the opinion of the NHRI and its call for the inclusion of a reference to human dignity. The government acknowledges human dignity as a source of human rights. However, it rejects the idea of including the concept in the Constitution because of its inadequate amount of legal precision (Kamerstukken II (Parliamentary Papers of the Second Chamber) 2015/16, 54516, no. 3, p. 5).

It remains to be seen how Parliament will handle the bill. The Second Chamber has the power to make amendments and could choose to introduce a reference to human dignity in the general provision. However, given the current state of affairs in Parliament, it is highly unlikely that any reference to the concept of human dignity will be included in the Constitution in the foreseeable future.

\section{References to Human Dignity in Legislation}

\subsection{Human Dignity in Legislative Texts}

The lack of a constitutional provision on human dignity does not prevent the occurrence of the concept of human dignity in a limited number of provisions in ordinary legislation. A number of provisions in Dutch equal treatment legislation - inter alia Section 1a Algemene Wet Gelijke Behandeling (Equal Treatment Act) and Section 7:646 Burgerlijk Wetboek (Civil Code) - deal with the prohibition of (sexual) harassment. Influenced by the EU Equality Directives, harassment is defined in those sections as conduct which has the purpose or effect of violating the dignity of a person and creating an intimidating, hostile, degrading, humiliating or offensive environment. Section 6.1a of the Vreemdelingenbesluit 2000 (Aliens Decree 2000) requires that the expulsion of aliens is executed in observance of the dignity and physical integrity of the alien. In the Act implementing the EU E-Commerce Directive (2000/31/EC) the prevention, investigation, detection and prosecution of criminal offences, including the protection of minors and the fight against any incitement to hatred on grounds of race, sex, religion or nationality, and violations of human dignity concerning individual persons, can serve as a ground to derogate from the freedom to provide information society services from another EU Member State. Again in this case, the reference to human dignity directly stems from the text of the EU Directive. 
The Wet internationale misdrijven (International Crimes Act), an Act establishing Dutch jurisdiction over serious violations of international humanitarian law committed abroad, penalises acts of apartheid and other inhuman or degrading practices that violate human dignity which are based on racist grounds, in case these acts or practices are committed during either an international or a non-international armed conflict. The International Crimes Act also penalises other violations of the laws and customs of war and indicates that should such offences involve outrages committed upon personal dignity, in particular degrading or abusive treatment, this would be seen as an aggravating factor leading to a higher penalty. Also in this case, the reference to human dignity is a result of developments in international law, since the International Crimes Act was mainly meant as an implementation of the obligations of the Netherlands under the 1998 Rome Statute of the International Criminal Court (ICC).

Apart from the examples mentioned above, no further reference to the idea of human dignity or dignity of the individual can be found in Dutch legislation. Further rules can be found only at the level of municipal ordinances usually concerning the granting of permits or financial support for local events or attractions. In general, no permit or financial support will be given by municipal authorities for activities that violate human dignity or public morals. The inclusion of such clauses in municipal ordinances is the result of discussions after some incidents in which local entrepreneurs were planning the organisation of festivities which would include activities like "dwarf tossing" or "goose pulling". So here a combination of arguments regarding degrading treatment of humans as well as animal welfare caused the restrictions in local by-laws.

\subsection{Human Dignity as an Argument for Legislative Proposals}

The use of references in parliamentary or public debates on draft legislation occurs somewhat more often than the actual inclusion of such references in legislative texts. An early example of a parliamentary discussion in which the idea of human dignity had some significance was the debate in the mid 1980s on a bill regulating the prohibition and dissolution of associations and other legal persons. The bill allowed for such prohibition and dissolution by court decision at the request of the public prosecution service in case "the activities of a legal person are contrary to public order". The bill was criticised for its lack of precision, given the vagueness of the phrase "contrary to public order". Several scholars and non-governmental organisations argued that the bill would offer authorities excessive powers therefore interfering with the freedom of association. These criticisms encouraged the government to give a further explanation of the meaning of the disputed phrase. According to the government, "contrary to public order" needed to be understood in such a way that only acts and practices that impair the foundations of the legal order, unjustifiably interfere with the freedom of others or violate human dignity would be able to cause the prohibition and dissolution of a legal person. As an example of such a violation of human dignity, the government pointed to violent threats against 
political or ideological opponents and acts of racist propaganda or other forms of discrimination (Kamerstukken II (Parliamentary Papers of the Second Chamber) $1984 / 85,17476,5$, p. 3). The majority of parliament was satisfied with this limited interpretation of the disputed phrase, which was considered to set the tone for further interpretation and application by the courts.

A further survey of parliamentary practice during the last two decades shows that human dignity arguments can either be used in support of certain proposals or in an attempt to block a certain bill. Supportive human dignity arguments can for instance be found in debates on:

- some anti-discrimination laws, where on numerous occasions, the prohibition of discrimination is linked to the need for a further realisation of respect for the dignity of all individuals

- the proposal for a law criminalising the abuse of prostitutes who are victims of trafficking, in which the idea of criminalising forced prostitution is based inter alia on the grounds that such forced prostitution violates the human dignity of the women involved

- legislation to fight trafficking and forced marriages

- proposals to change the laws relating to the registration of gender in passports and other public records in order to strengthen the legal position of transgender and intersexual individuals

- the bill to approve the ratification of the UN Convention on the Rights of Persons with Disabilities

- legislation to streamline the building of new refugee centres, in order to prevent situations in which the high influx of refugees and asylum seekers would result in people sleeping on the streets

Arguments referring to human dignity in order to block the parliamentary approval of certain bills can be found in the following areas:

- legislation restricting the access to social security, social care and medical support of foreign nationals without residency status

- amendments to legislation concerning the offering of immediate necessities of life such as shelter, food, water and clothing to migrants residing illegally in the Netherlands

- certain amendments to the Embryo Act 2002, allowing for practices of prenatal screening of embryos, which is seen by opponents as a practice that will stimulate the occurrence of abortions

- the bill concerning medical research on humans, which in very rare circumstances allows for medical research on minors and legally incompetent individuals

- a number of bills adapting the social care and social support system in the Netherlands and basically restricting the access to such care and support as part of a policy of austerity measures

- legislation allowing for a complete temporary denial of social welfare benefits to individuals who have committed some kind of fraud 
As one might guess, human dignity arguments in general will play a certain role in parliamentary debates relating to issues closely connected to physical integrity and medical ethics (medical research and experiments), to social support and care for groups that are particularly vulnerable (female victims of domestic violence, trafficking or forced marriages; refugees and asylum seekers; elderly persons; persons with disabilities; transgender and intersexual individuals), to the position of unborn children (prenatal screening, abortion) and to the prohibition of discrimination.

A particular issue where human dignity is a factor in the parliamentary debates in the Netherlands is euthanasia. Seen from an international and comparative perspective, the Netherlands has a rather liberal legal approach to euthanasia, physicianassisted suicide, and other end-of-life practices. In parliamentary debates on the issue, references to human dignity are made quite often. The parliamentary debate on the Euthanasia Act is an example (Kamerstukken II (Parliamentary Papers of the Second Chamber) 1999/00, 26691, 4). However, human dignity arguments are used both by opponents and supporters of the liberal legislation. Opponents view the easy access to life ending assistance in cases where there are no signs of unbearable physical suffering as a violation of human dignity, whereas supporters view any state restrictions on free access to life ending assistance as a violation of individual autonomy and, as such, as a violation of human dignity also.

\section{Application of the Idea of Human Dignity in Dutch Case Law}

\subsection{The General Trend}

Given the fact that there is no constitutional provision on the inviolability of human dignity, nor a directly applicable treaty provision on human dignity, the idea of human dignity cannot be invoked as such in procedures before the Dutch courts. However, the idea of human dignity can play a role, and will be referred to, in order to strengthen a certain interpretation of a self-executing provision of a human rights treaty or a provision of national law.

For instance, in several cases, the courts have referred to the violation of human dignity in order to justify convictions for hate speech or discriminatory speech. Labelling a local politician "a racist" on Twitter was considered a violation of the personal dignity of the politician in question by the Court of Appeal in The Hague (ECLI:NL:GHDHA:2016:1143). Individuals have been convicted for discriminatory insults against homosexuals, Muslims, Jews and other minority groups in judgements in which the courts inter alia considered that the speech used by the suspect violated the human dignity of the members of the minority group (e.g., ECLI:NL:GHAMS:2010:BO0041; ECLI:NL:GHAMS:2016:296). In some murder cases, courts have argued that the particularly violent way in which the murder was committed showed a denial of human dignity of the victim (ECLI:NL: GHSGR:2000:AE0149). This tends to be a penalty-increasing factor in the court's judgement, resulting in long-term imprisonment. 
References to violation of human dignity have been used by the Supreme Court (ECLI:NL:HR:2010:BJ8669) and several appellate courts (e.g., ECLI:NL: GHAMS:2000:AA5014; ECLI:NL:GHSGR:2011:BR0686) in defining certain acts or practices as torture or degrading treatment in the context of the application of the International Crimes Act. In cases concerning the crime of trafficking before the criminal courts, the question whether or not a violation of human dignity has occurred is often a highly relevant one. For instance, persuading a young woman to work as a prostitute was not considered a violation of human dignity. This would have brought the facts of the case within the ambit of the crime of trafficking as defined in Section $273 \mathrm{f}$ of the Criminal Code. This, however, was not the case because the suspect had shown no clear intent of exploiting the woman (ECLI:NL: GHDHA:2016:168). The element of exploitation, which can be shown by an unequal division of the income between the prostitute and the "manager", is decisive for constituting the crime of trafficking. In these types of cases, references to the idea of human dignity are influenced by the fact that many international documents (like the UN Palermo Protocol) and the case law of the ECtHR on Article 4 ECHR (prohibition of forced labour) refer to this idea as well (e.g., ECLI:NL: GHDHA:2016:931; ECLI:NL:GHAMS:2016:303). Especially, the ECtHR case law on the prohibition of forced labour is proving to be highly relevant in outlining the government's obligations to fight the practice of trafficking.

On a completely different note, in a case concerning the payment of damages for physical injuries, the Supreme Court considered that denying someone the right to damages because of the fact that he or she is unconscious as a result of the injuries suffered would violate human dignity (ECLI:NL:HR:2002:AE2149).

The obligation to obtain an official permit of the local authorities for the exploitation of a "prostitution facility" was judged to serve public order, and as such an overriding reason compared to the public interest in the sense of the EU Directive on services in the internal market (2006/123/EC). The Afdeling bestuursrechtspraak van de Raad van State (Administrative Jurisdiction Division of the Council of State) judged that such a measure could not be regarded as one imposing an unjustified restriction on the freedom to provide services. It based its judgement inter alia on the CJEU consideration in case C-36/02 (Omega Spielhallen) that the legal order of the EU undeniably strives to ensure respect for human dignity as a general principle of law, which constitutes a legitimate interest capable in principle of justifying a restriction on the obligations imposed by EU law. The Administrative Jurisdiction Division of the Council of State considered that the system of permits served the purpose of protecting human dignity as a part of the protection of public order (ECLI:NL:RVS:2014:2495).

In cases concerning the expulsion of aliens, applicants regularly argue that the expulsion violates human dignity. Often, these human dignity arguments are connected to the principle of non-refoulement which is incorporated in Article 3 ECHR. Also, applicants in these types of cases tend to invoke Article 1 of the EU Charter on Fundamental Rights: "Human dignity is inviolable. It must be respected and protected." In recent years in particular, this has been argued in cases relating to the expulsion of asylum seekers to Southern European countries 
on the basis of the Dublin II Agreement. Applicants argued that the deplorable living circumstances in refugee centres in countries like Greece, Italy and Malta would stand in the way of sending them back to the country where they first set foot on European soil. Although there are some exceptions, the courts generally considered that the persons involved did not belong to a category of particularly vulnerable persons, so there was no real risk of either a violation of Article 3 ECHR or a violation of human dignity (ECLI:NL:RVS:2016:575). In these types of cases, the invocation of human dignity does not seem to have any genuine added value next to the protection already offered by Article 3 ECHR. Actually, in most of the cases, applicants stick to invoking Article 3 ECHR and the relevant case law of the ECtHR, in particular the judgement M.S.S. v. Belgium and Greece, without any further references to human dignity (ECLI:NL:RVS:2011:BR3771).

In cases concerning the application of administrative sanctions as a result of fraud in the sphere of social benefits, which may include a complete - sometimes temporary - denial of social benefits to the individual concerned, human dignity considerations come into play also. The administrative courts in the Netherlands tend to quote the case law of the ECtHR that "respect for human dignity and individual freedom" constitutes "the very essence" of the ECHR and should serve as an important principle underlying the interpretation of its guarantees, in particular of the right to respect for private life under Article 8 ECHR which is affected by these types of measures. However, such considerations actually never lead to the conclusion that a reduction or full denial of social benefits violates human dignity or Article 8 ECHR (e.g., ECLI:NL:RVS:2010:BL7842; ECLI:NL:CRVB:2008:BG8789).

\subsection{Some Eye-Catching Cases}

\subsubsection{Human Dignity and the Right to Personality}

In 1994, the Supreme Court of the Netherlands delivered a landmark judgement in the Valkenhorst Case (15 April 1994, Nederlandse Jurisprudentie (Dutch Case Law) 1994, no. 608). In that case, the court had to deal with the claim by a child born out of wedlock in the 1940s in a Roman Catholic institution providing support for unmarried mothers. The child claimed that this institution - Valkenhorst - owed her a duty to provide information provided by her mother which would disclose the identity of her father. Valkenhorst rejected this claim on the grounds that it owed a duty of confidentiality to the mother: during the mother's lifetime knowledge of the presumed identity of the child's biological father could only be disclosed with the mother's consent. The mother who was still alive at the time refused to give her permission.

The Supreme Court accepted the claim of the child. The legal basis for this ruling the court found in "the general right to personality, which lies at the roots of such constitutional rights as the right to respect of one's private life, the freedom of thought, conscience and religion and the freedom of expression and includes the right to know one's parents". The court pointed to the fact that this right had found international recognition in Article 7 of the UN Convention on the Rights of the 
Child - a treaty that at that time had not yet been ratified by the Netherlands. This framing of a right to know one's parents as part of a general right to personality to a large extent had been influenced by the views of Advocate-General Koopmans. The Advocate-General himself, according to his conclusion on the Valkenhorst Case, had been inspired by a judgement of the German Constitutional Court from 1989 in which the right of a child to know one's parents had been derived from the protection of human dignity as guaranteed by the German Constitution. Although the Supreme Court itself did not directly refer to the judgement of the German Constitutional Court, the views of the Advocate-General are incorporated in the judgement. Thus, the Valkenhorst Case is perhaps the clearest example of importing human dignity considerations from foreign constitutional jurisdictions into the Dutch legal order.

\subsubsection{Human Dignity and "Wrongful Life" Claims}

In 2005, in the famous "wrongful life" case of Baby Kelly, the Supreme Court again referred to the concept of human dignity. During her pregnancy, a woman consulted her midwife at the hospital because there were two cases of intellectual disability in her husband's family, due to a chromosomal disorder. The midwife did not think it necessary to investigate the matter any further. This was later considered a professional failure with dramatic effects. When born, baby Kelly turned out to have serious mental and physical handicaps from which she suffered severely. Had the parents known this, they most probably would have chosen to abort the pregnancy. The parents claimed damages - both on their own accord and in the name of Kelly - and their claims were sustained by both the appellate court and the Supreme Court (ECLI:NL:HR:2005:AR5213). In its judgement, the Supreme Court also considered moral arguments regarding this type of wrongful life claims. The Supreme Court took into account the argument that ordering the hospital to pay damages for not preventing the birth of this severely handicapped child could be seen as a violation of the dignity of human life, since it acknowledges that having not been born is preferable to living in a condition like hers. However, after careful consideration, the Court rejected - or better: circumvented - this argument by stressing that in attributing emotional damage it did not imply that Kelly's existence was a source of suffering. Damages were based exclusively on the fact that the midwife made a serious mistake with regard to the fundamental rights of the parents and according to the Supreme Court should receive recognition through financial compensation. Nevertheless, the fact that the Supreme Court considered the human dignity argument in such an extensive way, in absence of any explicit link to previous case law on the provisions of the Dutch Civil Code that regulate liability for professional mistakes, is rather unique. The Supreme Court's judgement was hailed as "convincing" because of its thorough and meticulous method of reasoning and as "doing justice to the interests of the child, the parents and society" for finding "the correct balance between the natural emotions of those concerned and the financial interests that were at issue" (Stolker 2007). It was also severely criticised (De Hartogh 2007). 


\subsubsection{Human Dignity and the Method of Assessing the Credibility of a Declared Sexual Orientation in Asylum Procedures}

In asylum procedures, it regularly happens that authorities are faced with the difficult task of assessing claims regarding sexual identity. Individuals claim to be gay and run the risk of ill-treatment if sent back to their country of origin.

In 2013, the Administrative Jurisdiction Division of the Council of State, considered that it needed guidance whether individuals, after having self-identified as gay, could be subjected to further investigation without unjustified interference with their fundamental right to integrity (Article $3 \mathrm{EU}$ Charter of Fundamental Rights) and respect for private and family life (Article 7 EU Charter of Fundamental Rights). A single question was posed by the Dutch court to the CJEU:

\footnotetext{
What limits do Article 4 of Council Directive 2004/83/EC of 29 April 2004 on minimum standards for the qualification and status of third country nationals or stateless persons as refugees or as persons who otherwise need international protection and the content of the protection granted, and the Charter of Fundamental Rights of the European Union, in particular Articles 3 and 7 thereof, impose on the method of assessing the credibility of a declared sexual orientation, and are those limits different from the limits which apply to assessment of the credibility of the other grounds of persecution and, if so, in what respect?
}

In its preliminary ruling, the CJEU provided guidance on prohibited steps in determining an asylum claim based on sexual identity. Self-identification of sexual identity is a starting point, but Member States are allowed to subject selfidentification to an assessment procedure. However, such assessments must not violate rights guaranteed by the Charter, specifically the right to respect to human dignity (Article 1) and the right to respect for private and family life (Article 7). The CJEU indicated that the assessment cannot be based on (a) stereotypes, such as knowledge of gay organisations or notions of how gay people behave, since the assessment should be based on the individual and personal circumstances; (b) questioning on sexual practices, as this would violate the right to respect private and family life; (c) submitting the applicant to tests to demonstrate sexual identity, since this would infringe human dignity and (d) adverse findings as a result of delay in declaring sexual identity: not declaring sexual orientation at the outset of an asylum procedure cannot be held against the applicant's credibility, as sexuality is an intimate aspect of sexual identity (ECLI:EU:C:2014:2406).

The Administrative Jurisdiction Division of the Council of State incorporated the considerations of the CJEU in its own judgement. While applying those considerations it concluded that the questioning practices used in the asylum procedure at hand - as well as the general policy of the Dutch asylum authorities on the issue were not contrary to human dignity. However, the Council of State ruled that the Dutch policy on the issue lacked precision, whereas this policy only indicated methods of investigation into sexual orientation that could not be used. The policy did not indicate investigatory methods or lines of questioning that were allowed to be used (ECLI:NL:RVS:2015:2170). Although not entirely explicit, this ruling of the Council of State seems to indicate that respect for human dignity in these specific 
and rather extraordinary circumstances requires quite a detailed policy, indicating what the officers in the field are allowed to do during asylum interviews.

\subsubsection{Human Dignity and Basic Needs of Immigrants Without a Residence Permit}

Perhaps the most sensitive issue in which human dignity considerations have played a role in the Netherlands in recent years is the issue of basic needs of immigrants unlawfully residing in the Netherlands. Restrictive policies for irregular immigrants have increased their social exclusion, making it more difficult for them to access the labour market, housing and social services. There are now categories of immigrants who live in highly marginal situations. Most of them are former asylum seekers who did not receive a residence permit and were evicted from refugee centres after having exhausted all legal remedies. Some of them are still supported locally, often with indirect support from local authorities.

In response to a complaint by the Association of Protestant Churches, the European Committee on Social Rights (ECSR) called for the Dutch national government in 2014 to implement a coordinated approach at national and municipal levels to ensure that the basic needs (shelter, clothes and food) of these groups of immigrants who seek help are met (Conference of European Churches (CEC) v. the Netherlands 2014). The ECSR in its decision inter alia referred to the judgement of the ECtHR in M.S.S. v. Belgium and Greece, in which the Court (in $\S 253$ ) did not exclude "the possibility that the responsibility of the state may be engaged in respect of treatment where an applicant, who was wholly dependent on state support, found herself faced with official indifference in a situation of serious deprivation or want incompatible with human dignity [italics by the author]". The ECSR also pointed to Resolution 1509 (2006) of the Parliamentary Assembly of the Council of Europe (adopted on 27 June 2006) which provides the following with regard to the status of migrants:

5. The Assembly considers that, as a starting point, international human rights instruments are applicable to all persons regardless of their nationality or status. Migrants in an irregular situation, as they are often in a vulnerable situation, have a particular need for the protection of their human rights, including basic civil, political, economic and social rights. (...)

13. In terms of economic and social rights, the Assembly considers that the following minimum rights, inter alia, should apply:

13.1. Adequate housing and shelter guaranteeing human dignity should be afforded to migrants in an irregular situation (...).

The Government had argued that the group of persons to whom the complaint related was not covered by the relevant articles of the European Social Charter (ESC) since Paragraph 1 of the Appendix of the Charter indicates that the Charter's standards can only be applied to foreigners insofar as they are nationals of other Parties, lawfully resident or working regularly within the territory of the Party concerned. In response to this objection the ECSR considered: 
When human dignity is at stake, the restriction of the personal scope should not be read in such a way as to deprive migrants in an irregular situation of the protection of their most basic rights enshrined in the Charter, nor to impair their fundamental rights, such as the right to life or to physical integrity or human dignity [emphasis by the author].

The ECSR ruling was not legally binding and ESC provisions are generally not considered to have a self-executing character, which prevents the Dutch courts from directly applying them. However, the considerations from the ECSR ruling - including the references to human dignity - were used by Dutch courts in order to demarcate the scope of Articles 3 and 8 ECHR, which were considered to be applicable to situations concerning the basic needs of immigrants unlawfully residing in the Netherlands. In a number of judgements, several courts referred to the ESCR ruling and also to the above-quoted phrase from M.S.S. v. Belgium and Greece in order to conclude that Article 3 or Article $8 \mathrm{ECHR}$, in special circumstances, place on the authorities the positive obligation to provide shelter and other basic needs ("bed, bath and bread" arrangements) to immigrants without a residence permit (e.g., ECLI:NL: CRVB:2014:4178; ECLI:NL:RVS:2015:3415). However, while underlining the positive obligation to provide basic needs to immigrants unlawfully residing in the Netherlands, the courts accepted the policy of the Dutch government to offer "bed, bath and bread" arrangements only to unlawfully residing immigrants that are willing to cooperate in their departure from the country and only at certain locations where the immigrants concerned would be subjected to certain limits with regard to their freedom of movement (ECLI:NL:CRVB:2015:3803; ECLI:NL:RVS:2015:4001). The fact that the courts deemed these restrictions to the basic needs arrangements justified was deplored by the National Human Rights Institute of the Netherlands. The Institute argued that arrangements to secure human dignity could not be made subject to a willingness to cooperate with the government or to undergo restrictions as to one's freedom of movement (College voor de Rechten van de Mens 2015).

\section{Conclusion}

The role of the concept of human dignity in the constitutional system of the Netherlands is a limited one. The Dutch constitution does not contain any explicit reference to human dignity, although some fundamental rights that are often considered as closely linked to the realisation of human dignity - the right to private life, the right to physical integrity - are enshrined in the first Chapter of the Constitution. Recent proposals by a specially established Royal Commission that was asked to update the Human Rights Chapter in the Constitution received little political support from the government. The Commission's proposal to incorporate a reference to the protection of human dignity as one of the general constitutional aims in a so-called general provision to the Constitution, did not receive any follow-up. The reluctance to incorporate notions like human dignity in the Constitution is to a large extent influenced by the traditionally sober character of the Constitution. Furthermore, when it comes to realising 
human dignity by way of protecting human rights, the role of the Constitution altogether is a meagre one. As a result of the monistic system with regard to the application of international law in the Dutch legal order and because of the far more developed nature of the limitation clauses in treaties like the ECHR and the ICCPR almost all Dutch legal debates are centred on human rights treaty standards.

In Dutch legislation, a handful of provisions can be found that explicitly mention human dignity. Again, often these provisions are to a high extent influenced by international or European law: implementation of EU equality directives, implementation of the ICC Statute, fulfilling positive obligations to fight trafficking as they have been established in ECtHR case law etc. As an argument in debates on legislative proposals, human dignity sometimes is a factor, particularly when it comes to issues closely linked to medical ethics or physical integrity: euthanasia, medical experiments and abortion. Although human dignity considerations give an extra dimension to these debates, and often make the debates on the proposed law more intense and in-depth, ultimately human dignity arguments do not lead exclusively in one direction. Some proposals are rejected as well as applauded on the basis of human dignity arguments.

Because of the fact that the Dutch Constitution lacks a provision on the inviolability of human dignity and no self-executing treaty provision exists either, it is impossible to invoke the concept of human dignity in court procedures as a source of law on a stand-alone basis. Nevertheless, Dutch courts refer to human dignity on some occasions: in hate speech cases, in certain criminal cases where the courts want to underline the particularly heinous character of the crime committed, in cases relating to trafficking and the exploitation of prostitutes, in expulsion cases where the applicant invokes the non-refoulement principle, and in cases concerning administrative sanctions resulting in the reduction or complete denial of social benefits. In these cases human dignity enters the vocabulary of the judge in order to explain the scope or interpretation of human rights standards that have been invoked by one of the parties in the case. Basically the trend is that Dutch courts will refer to human dignity if international and European bodies like the ECtHR, CJEU and Human Rights Committee do also. The fact that the EU Charter of Fundamental Rights in article 1 declares human dignity inviolable has increased the number of court cases in which the idea of human dignity is addressed. On a critical note, one might say that what the courts do is merely paying lip service to human dignity. The idea of human dignity is referred to without clear consequences. However, in some cases, Dutch courts have gone somewhat beyond this general trend. In the case concerning the method of assessing the credibility of a declared sexual orientation in asylum procedures and in the cases concerning basic needs for immigrants without a residence permit human dignity considerations - combined with human rights treaty standards - led to judgements with considerable policy consequences. Incidentally, Dutch courts have found inspiration with regard to human dignity somewhere else than in international human rights law: in the case law of the German Constitutional Court (human dignity as the basis for a general right to personality which include the right to know one's parents). 


\section{$7 \quad$ Cross-References}

Human Dignity in Europe: Introduction

Human Dignity in the EU

Human Dignity in Europe: Conclusion

\section{References}

Alkema EA (1984) Foreign relations in the Netherlands constitution of 1983. Netherlands International Law Review 31:307-331

Alkema EA (2012) Chapter 16, Netherlands. In: Shelton D (ed) International Law and Domestic Legal Systems: Incorporation, Transformation, and Persuasion. Oxford University Press Scholarship Online 2012, Oxford

Barkhuysen T, Van Emmerik ML, Voermans WJM (2009) De Nederlandse Grondwet geëvalueerd: anker- of verdwijnpunt? (Evaluating the constitution of the Netherlands: anchor point or point of disappearance?). Kluwer, Alphen aan den Rijn, pp 27-46

Brems E, Vrielink J (2010) Menselijke waardigheid in de Nederlandse Grondwet? Voorstudie ten behoeve van de Staatscommissie Grondwet (Human dignity in the Dutch Constitution? A preparatory study for the Royal Commission on the Constitution). Kluwer, Alphen aan den Rijn. Chapters 2 and 3

Cliteur PB, Voermans WJM (2009) Preambules (preambles). Kluwer, Alphen aan den Rijn

College voor de Rechten van de Mens (2014) Advies inzake wetsvoorstel Algemene bepaling Grondwet (Advisory opinion on the draft general provision of the Constitution), Utrecht 15 October 2014 [online]. Available at: https://www.mensenrechten.nl/publicaties/detail/ 34982. Accessed 21 Jul 2016

College voor de Rechten van de Mens (2015) On 26 November 2015: College teleurgesteld over uitspraken in de Bed Bad Brood zaken (Human Rights Institute disappointed over judgments on bed, bath, bread arrangements), public statement 26 November 2015 [online]. Available at: http://www.mensenrechten.nl/berichten/college-teleurgesteld-over-uitspraken-de-bed-badbrood-zaken. Accessed 21 Jul 2016

De Hartogh GA (2007) Schadevergoeding wegens onrechtmatig bestaan ('wrongful life') onvoldoende beargumenteerd (Insufficient justification for granting a wrongful-life claim). Nederlands tijdschrift voor geneeskunde 151(4):241

Kroes M, Gerbranda T (1993) Eindrapport Grondrechten evaluatie-onderzoek (final report evaluating the human rights provisions in the Dutch constitution). NJCM-Boekerij, Leiden. Chapter 1

Eindrapport van de staatscommissie van advies inzake de Grondwet en de Kieswet (Final report of the Royal Advisory Commission on the Constitution and the Electoral Law) (1971), The Hague, $\mathrm{p} 22$

Rapport Staatscommissie Grondwet (Report of the Royal Commission on the Constitution) (2010), The Hague, Chapter 4, pp. 35-42

Stolker CJJM (2007) Terechte schadevergoeding wegens onrechtmatig bestaan ('wrongful life') (Appropriate damages due to 'wrongful life'). Nederlands tijdschrift voor geneeskunde 151 (4): 240

Uzman J, Barhuysen T, Van Emmerik ML (2010) The Dutch supreme court: a reluctant positive legislator? In: van Erp J, van Vliet L (eds) Netherlands reports to the eighteenth international congress of comparative law - Washington 2010. Intersentia, Antwerp/Oxford/Portland, pp 423-467 


\section{Case Law}

Conference of European Churches (CEC) v. The Netherlands, Complaint No. 90/2013 (European Committee on Social Rights 1 July 2014)

Goodwin v. The United Kingdom, appl. no. 28957/95 (ECtHR 11 July 2002), § 90

Jehovah's witnesses of Moscow v. Russia, appl. no. 302/02 (ECtHR 10 June 2010), § 135

M.S.S. v. Belgium and Greece, appl. no. 30696/09 (ECtHR 21 January 2011), § 253

Omega Spielhallen, C-36/02 (CJEU 14 October 2004), § 34

I. v. The United Kingdom, appl. no. 25680/94 (ECtHR 11 July 2002), § 70 